\title{
PENINGKATAN KEMAMPUAN GURU SEKOLAH DASAR DALAM PEMBUATAN MEDIA PEMBELAJARAN BERBASIS MULTIMEDIA
}

\author{
Rizkayeni Marta ${ }^{1)}$, Vera Irma Delianti' ${ }^{2)}$, Yeka Hendriyani ${ }^{3)}$ \\ ${ }^{1}$ Prodi Pendidikan Teknik Informatika, Fakultas Teknik, Universitas Negeri Padang \\ Email : ${ }^{1}$ rizkayeni.marta@ft.unp.ac.id, ${ }^{2}$ vera5339@ft.unp.ac.id, ${ }^{3}$ yekahendriyani@ft.unp.ac.id
}

\begin{abstract}
The purpose of this article is to find out the improvement of ability of elemenatry school teachers in Gugus 01 Baringin Anam Kecamatan Baso kabupaten Agam to create multimedia based on learning media by using Macromedia Director aplication. The improvement of ability is measured by using pre-test and posttest. The pre-test result that given to 18 teachers gained an average of 46.4 and the post-test result gained an average of 78,89. Based on the data, the increased percentage of elementary school teacher's ability was $78,14 \%$. Thus, it can be concluded that there is an increase in the ability of elementary school teachers in Gugus 01 Baringin Anam Kecamatan Baso Kabupaten Agam.
\end{abstract}

Keywords : Learning Media, Macromedia Director, Multimedia

\section{INTISARI}

Tujuan dari artikel ini adalah untuk mengetahui peningkatan kemampuan guru Sekolah Dasar Gugus 01 Baringin Anam Kecamatan Baso Kabupaten Agam dalam pembuatan media pembelajaran berbasis multimedia menggunakan aplikasi Macromedia Director. Peningkatan kemampuan ini diukur dengan menggunakan soal pretest dan posttest. Hasil pretest yang diberikan kepada 18 orang guru memperoleh ratarata sebesar 46,4 dan hasil posttest yang diberikan kepada 18 orang guru memperoleh hasil rata-rata sebesar 78,89 . Berdasarkan rata-rata tersebut maka diperoleh persentase peningkatan kemampuan guru sekolah dasar sebesar 78,14\%. Dengan demikian, dapat disimpulkan bahwa terdapat peningkatan terhadap kemampuan guru Sekolah Dasar Gugus 01 Baringin Anam Kecamatan Baso Kabupaten Agam.

Kata kunci : Media Pembelajaran, Macromedia Director, Multimedia

\section{PENDAHULUAN}

Sistem pendidikan telah mengalami perkembangan yang pesat. Hal ini juga didukung oleh kemajuan Ilmu Pengetahuan dan Teknologi (IPTEK). Oleh karena itu, guru dan siswa sudah sewajarnya mengetahui, mengenal, dan mengikuti perkembangan IPTEK yang dapat menunjang proses pembelajaran. Guru dan sekolah harus berperan aktif supaya siswa mampu memahami dan mengerti setiap materi yang diberikan. Pemberian materi pelajaran haruslah dikemas sebaik mungkin sehingga dapat menimbulkan suasana dan lingkungan belajar yang baik dan nyaman. Hal ini bertujuan untuk menunjang hasil belajar siswa kedepannya.

SDN 01 Baringin Anam merupakan satu diantara sekolah dasar negeri yang terletak di Kabupaten Agam Kecamatan Baso. Hasil wawancara bersama salah seorang guru di SDN 01 Baringin Anam Baso diketahui bahwa proses pembelajaran yang dilaksanakan oleh guru masih secara konvensional dimana guru masih menggunakan bahan ajar berbasis teks dan papan tulis. Dalam pembelajaran konvensional, siswa dianggap sebagai orang yang belum mengetahui apa-apa dan hanya akan menerima apa yang disampaikan oleh guru [1]. Metode pembelajaran yang biasa digunakan di dalam pembelajaran konvensional adalah metode ceramah dimana guru bersifat sebagai sumber pengetahuan dan informasi. Selain itu, Proses pembelajaran juga bersifat monoton dimana guru menerangkan pembelajaran sedangkan siswa hanya mendengarkan apa yang dijelaskan dan disampaikan oleh guru. Pembelajaran yang bersifat monoton tersebut memicu siswa untuk merasa 
bosan, ngantuk, mengganggu teman-teman lainnya, dan tidak tertarik dengan pembelajaran yang disampaikan. Hal-hal tersebut nantinya akan mempengaruhi terhadap hasil belajar siswa.

Upaya untuk meminimalisir hal tersebut salah satunya adalah dengan pembuatan media pembelajaran berbasis multimedia dengan mengunakan aplikasi Macromedia Director. Media pembelajaran adalah salah satu bentuk rangsangan atau stimulus yang berfungsi untuk menyampaikan pesan dalam proses pembelajaran [2]. Stimulus bisa digunakan sebagai media dalam interaksi manusia, realita, gambar bergerak atau tidak, tulisan dan suara yang direkam. Stimulus tersebut akan membantu peserta didik dalam mempelajari bahasa asing. Kemudian pemberian stimulus ini dapat membuat peserta didik untuk berpikir kritis. Media pembelajaran adalah segala sesuatu yang ada di lingkungan baik berupa alat ataupun kegiatan yang berguna untuk menambah pengetahuan, mengubah sikap atau menanamkan keterampilan pada setiap individu [3].

Penggunaan media pembelajaran harus menyesuaikan dengan materi ajar yang akan diajarkan oleh guru di dalam kelas. Sebuah media pembelajaran seharusnya memiliki berbagai kriteria, diantaranya yaitu menarik (baik dari sisi tampilan ataupun konten) dan mampu membantu peserta didik dalam mencapai tujuan pembelajaranya.

Fungsi utama dari media pembelajaran adalah sebagai sumber belajar [4]. Dimana media pembelajaran memberikan gambaran yang lebih jelas mengenai pembelajaran yang disampaikan oleh guru. Fungsi media adalah untuk memperjelas, memudahkan dan membuat pesan pembelajaran yang disampaikan oleh guru kepada peserta didik menarik sehingga menjadi motivasi dan mengefisienkan proses belajar [2]. Adapun tujuan media pembelajaran adalah mengefektifkan proses komunikasi pembelajaran sehingga tercapai tujuan yang diinginkan (adanya perubahan tingkah laku)

Hal tersebut dapat dicapai apabila guru menerima informasi yang benar mengenai media pembelajaran berbasis multimedia. Salah satunya adalah informasi mengenai penggunaan aplikasi Macromedia Director[5]. Media pembelajaran berbasis multimedia ini dapat digunakan guru di dalam kelas melalui cara yang menarik dalam mengenalkan teknologi kepada peserta didik, memicu kreativitas, meningkatkan rasa ingin tahu yang akan memicu peningkatan hasil belajar. Selain itu, media pembelajaran ini juga dapat digunakan oleh peserta di luar kelas untuk mengulang materi pelajaran sehingga dapat dipahami lebih lanjut.

\section{PENDEKATAN PEMECAHAN MASALAH}

\section{Metode}

Metode yang digunakan kepada guru-guru SD di Gugus 01 Baringin Anam Baso Kabupaten Agam yaitu berupa pelatihan/workshop. Setelah pembelajaran diberikan kepada guru-guru maka guru-guru diminta untuk menerapkan hasil pembelajaran tersebut di dalam pembuatan media pembelajaran guna memanfaatkan aplikasi Macromedia Director dalam pembelajaran.

Langkah-langkah dalam metode pembelajaran yang diberikan sebagai berikut:

1. Langkah Awal; Penentuan dan peninjauan lokasi dan sasaran, dan penyusunan bahan/materi pembelajaran berupa makalah dan modul yang akan digunakan selama kegiatan pembelajaran.

2. Pelaksanaan; Pelatih menjelaskan aplikasi Macromedia Director dan cara pengaplikasiannya dalam proses pembelajaran di kelas bagi guru; Pembelajaran yang diberikan menitikberatkan pada kemampuan guru dalam pembuatan media pembelajaran. Pembelajaran ini dilaksanakan menggunakan teknik demonstrasi dimana para guru bisa menyaksikan secara langsung proses dan langkah-langkah pembuatan media pembelajaran berbasis multimedia yang didemonstrasikan oleh pelatih kemudian guruguru dapat melakukannya setelah melihat hasil peragaan dari pelatih. Selain mendapatkan pengalaman langsung, guru-guru juga mendapatkan pengayaan dari teman-temannya dan tim pelatih.

3. Pembelajaran

Pelaksanaan pembelajaran menggunakan beberapa metode, yaitu: (1) Metode Ceramah; penjelasan yang diberikan kepada guru untuk mendapatkan informasi terkait aplikasi Macromedia Director dan cara pengaplikasiannya dalam pembelajaran di kelas, (2) Metode Tanya Jawab; untuk menerima penjelasan terkait pengetahuan yang dibahas serta langkah-langkah dalam pengaplikasiannya. Selain itu, guru-guru bisa mendapatkan pengetahuan dengan cara menggali sebanyak-banyaknya terkait topik yang dibahas, dan (3) Metode Demonstrasi; kesempatan bagi guru-guru dalam mengaplikasikan materi pembelajaran yang diperoleh. 
Selain itu, peserta juga diberikan pengetahuan meliputi pengenalan aplikasi Macromedia Director, manfaat aplikasi Macromedia Director, dan tata cara dalam pembuatan media pembelajaran menggunakan aplikasi Macromedia Director. Peningkatan minat dan keterampilan guru-guru dalam pemanfaatan media pembelajaran berbasis multimedia menggunakan aplikasi Macromedia Director sangat diharapkan di dalam pembelajaran. Informasi yang diberikan kepada guru mengenai aplikasi Macromedia Director dapat digunakan untuk pembuatan media pembelajaran berbasis multimedia yang menarik sehingga akan menimbulkan proses interaksi di dalam pembelajaran. Selain itu, penggunaan media pembelajaran berbasis multimedia ini dapat memicu minat, ketertarikan peserta didik, rasa ingin tahu, motivasi serta dapat meningkatkan hasil belajar peserta didik.

Peserta diharapkan mampu menguasai materi pembelajaran yang diterima, mengetahui tingkat kemampuannya dalam menerapkan materi dan kemudian mengidentifikasi kesulitan-kesulitan (jika masih ada) untuk kemudian dipecahkan. Tingkat pemahaman peserta mengenai materi diukur dengan pelaksanaan pretets dan posttest.

Pretest merupakan tes awal yang diberikan dengan tujuan untuk mendapatkan gambaran awal mengenai pengetahuan dasar peserta terkait materi yang akan diberikan. Sedangkan posttest merupakan tes di akhir materi dengan tujuan mengetahui sejauh apa pengetahuan yang telah diberikan dapat diserap oleh peserta.

Pretest-posttest merupakan analisis data yang berdampingan. Pemberian pretest dan posttest haruslah pada unit eksperimental yang sama diukur pada variable yang sama pada waktu yang berbeda atau pada waktu yang sama dalam kondisi yang berbeda [6].

\section{HASIL DAN PEMBAHASAN}

Hasil dari kegiatan pembelajaran berupa media pembelajaran berbasis multimedia. Media pembelajaran berbasis multimedia ini dibuat menggunakan aplikasi Macromedia Director berdasarkan mata pelajaran yang diampu oleh masing-masing guru. Selain itu, hasil dari kegiatan pembelajaran ini berupa peningkatan pengetahuan guru-guru dalam menggunakan aplikasi Macromedia Director. Hal ini dapat dilihat berdasarkan nilai pretest dan posttest.

Pretest dan posttest diberikan kepada peserta pembelajaran berupa soal objectif sebanyak 30 buah. Soal yang diberikan berisi pengetahuan terkait pembuatan media pembelajaran menggunakan aplikasi Macromedia Director. Pemilihan metode pretest dan post ini digunakan supaya pendidik mampu memilih metode dan strategi dalam pelaksanaan pembelajaran.

Jika hasil posttest lebih baik dari hasil pretest dan persentase peningkatan menunjukkan angka yang lebih dari $75 \%$ maka dapat dikatakan bahwa pembelajaran yang diberikan kepada guruguru SD Gugus 01 Baringin Anam berpengaruh dalam peningkatan kemampuan dalam pembuatan media pembelajaran berbasis multimedia. Hasil pretest dan posttest yang telah dilaksanakan dalam pembuatan media pembelajaran berbasis multimedia dapat dilihat pada Tabel 1.

Table 1 di bawah memperlihatkan bahwa rata-rata hasil pretest yang dilaksanakan oleh 18 orang guru sebesar 46,4 dan rata-rata hasil posttest yang dilaksanakan oleh 18 orang guru sebesar 78,89 . Hasil tersebut menunjukkan bahwa terjadi peningkatan kemampuan dan pengetahuan guruguru Sekolah Dasar Gugus 01 Baringin Anam Kecamatan Baso Kabupaten Agam dalam memahami aplikasi Macromedia Director sebesar 78.14\%. Selain itu, hasil tersebut juga mengindikasikan bahwa guru-guru Sekolah Dasar Gugus 01 Baringin Anam telah mampu merancang dan membuat media pembeajaran berbasis multimedia menggunakan aplikasi Macromedia Director. 
Tabel 1. Hasil Pretest dan Posttest Kegiatan Pembelajaran

\begin{tabular}{cccccc}
\hline No & Nama & Pretest & Posttest & Persentase (\%) Peningkatan & Gain Score \\
\hline 1 & Peserta 1 & 52 & 76 & 46.15 & 0.5 \\
2 & Peserta 2 & 32 & 76 & 137.5 & 0.6 \\
3 & Peserta 3 & 44 & 80 & 81.81 & 0.6 \\
4 & Peserta 4 & 44 & 80 & 81.81 & 0.6 \\
5 & Peserta 5 & 68 & 76 & 11.76 & 0.3 \\
6 & Peserta 6 & 28 & 80 & 185.71 & 0.7 \\
7 & Peserta 7 & 44 & 80 & 81.81 & 0.6 \\
8 & Peserta 8 & 48 & 84 & 75 & 0.7 \\
9 & Peserta 9 & 60 & 88 & 46.67 & 0.7 \\
10 & Peserta 10 & 56 & 80 & 42.86 & 0.5 \\
11 & Peserta 11 & 52 & 76 & 46.15 & 0.5 \\
12 & Peserta 12 & 44 & 80 & 81.81 & 0.6 \\
13 & Peserta 13 & 44 & 80 & 81.81 & 0.6 \\
14 & Peserta 14 & 32 & 84 & 162.5 & 0.8 \\
15 & Peserta 15 & 48 & 64 & 33.33 & 0.3 \\
16 & Peserta 16 & 48 & 76 & 58.33 & 0.5 \\
17 & Peserta 17 & 40 & 76 & 90 & 0.6 \\
18 & Peserta 18 & 52 & 84 & 61.54 & 0.7 \\
\hline \multicolumn{7}{r}{} & JUMLAH & $\mathbf{8 3 6}$ & $\mathbf{1 4 2 0}$ & & $\mathbf{7 8 . 1 4}$ & \\
\hline
\end{tabular}

\section{KESIMPULAN}

Kegiatan pembelajaran yang telah dilaksanakan di SDN 01 Baringin Anam menunjukkan adanya peningkatan kemampuan guru-guru Sekolah Dasar Gugus 01. Hal ini dapat dilihat dari nilai pretest dan posttest yang telah dilaksanakan oleh guru-guru. Nilai rata-rata yang diperoleh dalam pelaksanaan pretest sebesar 46.4 dan nilai rata-rata dalam pelaksanaan posttest sebesar 78,89. Persentase peningkatan kemampuan guru berdasarkan hasil pretest dan posttest sebesar $78,14 \%$.

\section{DAFTAR PUSTAKA}

[1] Sahimin. 2017. Pengaruh Model Pembelajaran Dan Gaya Belajar Terhadap Hasil Belajar PAI Siswa Kelas VII Smp Negeri 1 Kabanjahe Kabupaten Karo. UIN Sumatera Utara. Jurnal Vol.1, No. 2, April - Juni 2017, diambil tanggal 15 April 2019, dari http://jurnal.uinsu.ac.id/index.php/eduriligia/a rticle/download/894/689.

[2] Rusman, dkk. 2011. Pembelajaran Berbasis Teknologi Informasi dan Komunikasi. Jakarta: PT. Raja Grafindo Perasada.

[3] Wina Sanjaya. 2014. Media Komunikasi Pembelajaran. Jakarta: Kencana.

[4] Yudi Munadi. 2008. Media Pembelajaran Sebuah Pendekatan Baru. Jakarta: Gaung Persada Press.

[5] Y. Hendriyani, H. Effendi, and G. Farell, "Pembelajaran Pengembangan Media Pembelajaran Interaktif Berbasis Ict Bagi
Guru-Guru Di Smp Negeri Di Kecamatan Harau, Kabupaten Lima Puluh Kota," UNES J. Community Serv., 2018.

[6] Ilham Effendy. 2016. Pengaruh Pemberian Pretest dan Posttest Terhadap Hasil Belajar Mata Diklat HDW.DEV.100.2.A Pada Siswa SMK Negeri 2 Lubuk Basung. UNP. Jurnal Vol 1 No. 2, Oktober 2016, diambil tanggal 09 September 2019, dari http://jurnal.untirta.ac.id/index.php/VOLT/art icle/download/2873/2248. 